\title{
The Postdigital in Pandemic Times: a Comment on the Covid-19 Crisis and its Political Epistemologies
}

\section{Mark Coeckelbergh ${ }^{1}$}

Published online: 19 April 2020

(C) Springer Nature Switzerland AG 2020

Keywords Covid-19 · Pandemic · Postdigital · Politics · Epistemology · Phenomenology · Philosophy of technology $\cdot$ Risk

\section{Digitize or Die!}

What does the 'digital' and 'digitalization' mean today, for education and in general? Instead of jumping to an abstract theoretical discussion in the literature, let me start with something concrete, very concrete unfortunately: the current Covid-19 pandemic that currently disrupts our lives and societies.

With regard to understanding our relation to the digital and digital technologies, this crisis seems to present us with a challenging paradox. On the one hand, it seems that there is very little 'virtual' or 'digital' about it; instead, reality violently breaks in. This crisis, understood as an event, is not about otherworldly digital spaces or virtual worlds but about all too real bodies, viruses, face masks, ventilators, and coffins. It almost seems like reality takes revenge: 'You were fascinated by computers, the Internet, and your social media. But what does it all matter now, huh? Forget about your digital revolution and your ideas about new skills for a bright digital future; education should be about learning real skills such as medical care and something you thought belongs to another century: how to properly wash your hands.' The virus will help you to get rid of your obsession with numbers and theory.

One the other hand, the digital and digitalization seems more important than ever: in times of Covid-19, it becomes clear that we were much too slow with digitalizing education, work, and other fields, and we should be damn lucky that we have all our digital tools to communicate and get information in times of lockdown: our lives literally depend on them. If we can go on with our lives and education, it is because - thank god - we still have these digital technologies. Again, we are taught a lesson: 'You (teacher, employer, politician) believed you have still years to implement

Mark Coeckelbergh

mark.coeckelbergh@univie.ac.at

1 University of Vienna, Vienna, Austria 
digitalization in your organization, practices, and country. And you, students, employees, citizens, you believed you could go on as always with your miserable, unenhanced offline lives. You were so wrong. If you didn't listen to us, experts, the virus will teach you now, digital analphabets. Digitize or die!'

Luckily, however, the paradox is just that: a paradox. It is only an apparent opposition; it can be resolved and this is how: Both points of view assume a false opposition between, on the one hand, a 'virtual' unreal sphere called the 'digital' and 'online' and, on the other hand, a 'real' sphere called 'analogue' and 'offline.' This metaphysics has been successfully criticized in both 'postdigital' studies and philosophy of technology. Postdigital scholars have argued that we no longer live in a world where digital technologies and media constitute 'a separate, virtual "other" to a "natural" human and social life' (Jandrić et al. 2018: 893). The technologies and media are taken for granted and hardly deserve a separate term anymore. Philosophers of technology have also defended the view that today there is no longer an opposition between a cyber world and a face-to-face experience and that the digital is now 'integrated and imbricated with our everyday actions and interactions,' as Andrew Feenberg (2019: 8) has recently argued in this journal. Similarly, Luciano Floridi (2015: 1) has coined the term 'onlife' to refer to 'the new experience of a hyperconnected reality within which it is no longer sensible to ask whether one may be online or offline.'

\section{We Have Always Been Postdigital}

I propose to go further: these views assume that first there were two spheres, which then got merged. But there probably never even was a separate sphere or such an opposition between virtual and real in the first place, and it never has been sensible to make the online/offline distinction, at least if that distinction is supposed to have ontological significance. We have always been 'postdigital' from the beginning of the so-called digital revolution. When are using the Internet and 'online' media and technologies, 'we do not leave our bodies at home' (Coeckelbergh 2013: 13) and neither are we separate from others or from socalled external or offline reality; from a phenomenological and non-dualist point of view, our use of these media and technologies must be understood in terms of living experience that is embodied, social, and real. Platonic and modern dualisms are still very influential, but we can at least try to think in a way that goes beyond a dualist platonic split of the world into real and unreal.

From this perspective, then, the paradox assumes a misguided view of the world. Covid-19 presents us not with challenges concerning 'the digital' as opposed to something else. It presents us with challenges - full stop - and these challenges have to do with things that are immaterial and material, or both at the same time. They are also social challenges. The crisis is not only about numbers and statistics but also about material things such as masks and soap, about people and what they do together, and about the technologies and infrastructures we use - as related to social interests. Science and technology studies (STS) scholars have done a good job to hammer down that point. Latour (1993) talks about 
'hybrids.' We live in a hybrid world, and we have always done so. The Covid-19 crisis is an event that takes place within such a world. The problem is not that we must choose between the cave and the free world outside; the point is that there is no such platonic setup in the first place.

\section{The Phenomenology and Epistemology of Risk}

But enough about what the world really 'is' like. Centuries after Kant and decades after Foucault, let us not be philosophically naïve and let us talk about epistemology and politics instead of metaphysics. What can we know and how do we know about the virus and the crisis? And is the crisis not more about what happens and what might happen rather than what 'is'? The questions we (should) ask today are not 'What is this thing called Covid-19?' or 'What 'is" this or that technology (digital or not)?,' but 'What is the risk?,' 'How do I know the risk?,' 'What makes possible my experience of the risk?,' 'What is the role of technology in relation to that risk?' and 'Who decides about, and shapes, (my knowledge and experience of) the risk and the technologies involved?'

And here too it is important to take less dualist view. In Human Being @ Risk (2013), I offer an existential-phenomenological approach to argue that risk is neither an objective feature of the world or external state of affairs, nor something that we construct in our mind, but is constituted in the subject-object relation or goes beyond that subject-object binary altogether. I use the terms 'being-vulnerable' and 'being-at-risk' to refer to the lived and active relation we have to the world, an openness to the world that puts us at risk and makes us vulnerable as humans-in-relation (Coeckelbergh 2013: 43). Technologies shape, transform, and mediate this 'being-at-risk'; that is, they shape our vulnerability and risk as lived and enacted risk that is neither purely subjective nor purely objective. From a philosophy of technology point of view, it is therefore important to consider how technologies we call 'digital,' and also other technologies such as material infrastructures, shape what we know about the crisis and 'the virus.' As philosophy of technology and media studies have shown, technologies and media always have noninstrumental roles and non-intended effects. This is also the case here. Think for instance how my experience of the crisis and Covid-19 is shaped by my participation in 'digital' social media. Such media do not merely 'communicate' about some kind of 'external' risk or 'thing'; they also shape my 'being-at-risk' as an experiencing being that actively relates to the world and to others.

\section{Power and the Shaping of Risk}

For education, this means that educational technologies including so-called digital media - whatever their metaphysical status may be - may play a crucial role not so much in the 'perception' of risk and vulnerability by children and young people (as if risk were merely something that is external to them) but rather in shaping their lived and experienced vulnerabilities, their 'being-at-risk'. This means for teachers that in these times (and all other times), it is important to think about not only the content of their teaching but also the medium they use. 
Teachers are also important since, regardless of their intention and like all others who have a leading role in this crisis, they not only intervene with regard to knowledge and experience but also unavoidably exercise power in relation to that knowledge. From a political-epistemological point of view, it is important to ask who defines what the crisis 'is,' who shapes the risk and defines the risk, and who decides about life and death. Covid-19 is not only a 'thing' but also reveals power relations in their full significance: the raw power exercised by governments when they take measures that restrict the freedom of people (and in some cases use the crisis to assume dictatorial powers) and also the less visible or more subtle power games that take place in hospitals, schools, and families. As Foucault (1980) argued, power is also present in all kinds of relations and hence is exercised by everyone. Medical professionals not only decide about life and death and make ethical decisions without ethical commissions but also define what we should know about the virus and discipline us, for example, with regard to hygiene. Teachers exercise surveillance and discipline and manipulate the behavior of their students through 'online' technologies. Power relations in families become more visible in times of lockdown.

We can and should also ask about the labor that goes into 'constructing' or 'producing' the risk - for example, in and by 'digital' social media, for which we also do digital labor - and of course in dealing with the risk. Who carries the biggest burden? Who might even benefit from this crisis? These are not questions that concern theoretical fights about 'digital' and 'non-digital,' or tensions between metaphysical views of the world. These problems concern (knowledge of) risk as related to power relations between embodied people whose lives are pervaded by so-called digital technologies and other technologies and who actively use these technologies to cope with the crisis: to treat the sick, to govern, and to educate, thereby producing effects on their bodies-minds and on others.

This gives teachers and other professionals an important responsibility when (taking decisions about) using 'digital' and other media and technologies, in times of crisis and at other times. If teaching and its technologies can be conceived as what Foucault called 'technologies of the self' that affect people's 'bodies and souls, thoughts, conduct, and way of being' (Foucault 1988: 18), then at stake is not just 'education,' narrowly defined. At stake is, as all good teachers know, how to shape the lives and future of human beings.

\section{References}

Coeckelbergh, M. (2013). Human being @ risk: enhancement, technology, and the evaluation of vulnerability transformations. Dordrecht: Springer.

Feenberg, A. (2019). Postdigital or Predigital? Postdigital Science and Education, 1(1), 8-9. https://doi. org/10.1007/s42438-018-0027-2.

Floridi, L. (2015). Introduction. In L. Floridi (Ed.), The online manifesto: being human in a hyperconnected era. Cham: Springer.

Foucault, M. (1980). Power/knowledge. Trans. C. Gordon and L. Marshall. New York: Pantheon Books.

Foucault, M. (1988). Technologies of the self: a seminar with Michel Foucault. Amherst: The University of Massachusetts Press.

Jandrić, P., Knox, J., Besley, T., Ryberg, T., Suoranta, J., \& Hayes, S. (2018). Postdigital science and education. Educational Philosophy and Theory, 50(10), 893-899. https://doi.org/10.1080 /00131857.2018.1454000.

Latour, B. (1993). We have never been modern. Cambridge, MA: Harvard University Press. 